\title{
Relationships between pasture forage components and fecal chemical composition
}

\author{
J.F. KARN AND L. HOFMANN
}

\begin{abstract}
A major problem in evaluating nutritional quality of the grazing animal's diet is collecting forage representative of that being grazed. We compared the chemical composition of simulated diet (SD) and mower clipped (MC) forage samples to each other and to fecal chemical composition data. Forage from crested wheatgrass [Agropyron desertorum (Fischer ex. Link) Schultes], western wheatgrass [Pascopyrum smithii (Rydb.) A. Löve], smooth bromegrass (Bromus inermis Leyssor), Russian wildrye [Psathyrostachys juncea (Fisher) Nevski], and native range pastures was collected every 2 weeks beginning 14 June and continuing through 20 September 1983. Fresh fecal samples from grazing steers were obtained 2 days following forage collections. Variability among individuals hand clipping forage to simulate a grazing animal's diet was less than the variability between mower strips for in vitro digestible organic matter (IVDOM), calcium (Ca), and magnesium $(\mathrm{Mg})$. Correlation coefficients between SD and MC residuals were low. Coefficients between SD and fecal residuals were higher for acid detergent fiber (ADF), IVDOM, Ca, and phosphorus (P) than coefficients for the same variables obtained with MC and fecal data. The highest coefficients using residual data were achieved with fecal $\mathrm{Ca}$ and SD ADF, cellulose, $\mathrm{C} a$, and $\mathrm{Mg} r=-0.84,-0.81$, 0.84 , and 0.81 , respectively. Interactions involving pastures and sample dates were significant for the same effects for $P, A D F$, cellulose, and IVDOM for SD and fecal data. Data suggest that some fecal components, primarily $\mathrm{Ca}$, may be useful in predicting the diet quality of grazing cattle, but these relationships need further examination.
\end{abstract}

Key Words: mower clipped, simulated diet, cool-season pastures, native range, nitrogen

Authors are research animal scientist and research agronomist, USDA-ARS Northern Great Plains Research Laboratory, P.O. Box 459, Mandan, N. Dakota 58554.

Authors wish to thank Dr. Gary V. Richardson, mathematical statistician, for assistance with statistical procedures, and $\mathrm{Mr}$. Richard $\mathrm{E}$. Huppler and $\mathrm{Mr}$. Gordon A. Jensen for technical assistance.

Manuscript accepted 29 November 1989.
The diet quality of grazing animals is difficult to determine, whether they are grazing mixed prairie or seeded monoculture forages. Diet quality is often determined using hand or mechanically clipped forage obtained from a randomly located quadrat. Such samples are relatively easy to obtain, but the clipped forage is often not representative of forage selected by grazing animals. Bredon et al. (1967) documented selectivity of grazing animals when they found that diet forage samples obtained via esophageal fistula were higher in crude protein and lower in crude fiber than clipped forage samples. Although fistula forage samples do account for animal selectivity, they also bear the effects of mastication and contamination by saliva, which makes them questionable for mineral analysis (Hoehne et al. 1967, Scales et al. 1974). Small pastures used in many production studies are also unsuitable for sampling with fistulated animals because forage production may be inadequate to support both tester and fistulated animals. Wallace et al. (1972) reported a method of simulating diet samples, but the procedure was time consuming and still depended on esophageal fistula collections. Hart et al. (1983) indicated that chemical composition of hand clipped whole plant samples containing the primary species being grazed by cattle declined more rapidly than esophageal fistula diet samples. Investigators have recently examined the feasibility of estimating diet quality through fecal analyses (Erasmus et al. 1978, Holechek et al. 1985, Hakkila et al. 1988). The availability and convenience of fecal samples makes them a potentially valuable means of indirectly assessing diet quality; however, their reliability and accuracy in this regard must be proven.

The objectives of this study were: (1) to compare the chemical composition of hand clipped forage selected to simulate the grazing animal's diet and cutter bar mower clipped forage; and (2) to compare the chemical composition of forage sampled by both methods with fecal data.

\section{Materials and Methods}

Four cool-season pastures, crested wheatgrass [Agropyron 
Table 1. Mower clip (MC) and simulated diet (SD) variance estimates and their relative F-ratios.'

\begin{tabular}{|c|c|c|c|c|c|c|c|c|c|}
\hline \multirow[b]{2}{*}{ Item } & \multicolumn{9}{|c|}{ Constituent } \\
\hline & IVDOM $^{2}$ & $\mathbf{N}$ & $\mathrm{ADF}^{2}$ & Lignin & Cellulose & $\mathrm{Ca}$ & $\mathbf{P}$ & $\mathrm{Mg}$ & $\mathbf{K}$ \\
\hline $\mathrm{EA}^{3}$ variance $(\mathrm{MC})$ & 7.47 & 0.02 & 2.68 & 0.19 & 1.83 & 0.0889 & 0.00022 & 0.00976 & 0.088 \\
\hline$E \Lambda^{3}$ variance (SD) & 0.68 & 0.10 & 1.27 & 1.53 & 1.90 & 0.0065 & 0.00013 & 0.00065 & 0.021 \\
\hline F-ratio & $10.90^{*}$ & 4.36 & 2.11 & $8.23^{*}$ & 1.04 & $13.67^{*}$ & 1.66 & $15.02^{*}$ & 4.15 \\
\hline $\mathrm{EB}^{4}$ variance $(\mathrm{MC})$ & 2.58 & 0.04 & 2.77 & 0.59 & 2,85 & 0.0720 & 0.00037 & 0.00376 & 0.073 \\
\hline $\mathrm{EB}^{4}$ variance $(\mathrm{SD})$ & 1.87 & 0.03 & 1.72 & 1.00 & 1.99 & 0.0017 & 0.00014 & 0.00027 & 0.018 \\
\hline F-ratio & 1.38 & 1.10 & 1.60 & 1.70 & 1.43 & $42.34^{*}$ & $2.68^{*}$ & $13.72^{*}$ & $4.18^{*}$ \\
\hline
\end{tabular}

IF-ratio = larger variance divided by smaller variance.

2IVDOM = in vitro digestible organic matter and ADF = acid detergent fiber.

${ }^{3}$ Error $A$ is the pasture by individual or pasture by mower strip interaction, degrees of freedom $=4$.

${ }^{4}$ Error $B$ is a combination of the date by pasture interaction and the 3-way interaction, degrees of freedom $=35$.

*F-ratios were significant at the $5 \%$ probability level.

desertorum (Fischer ex. Link) Schultes] (CW), Russian wildrye [Psathyrostachys juncea (Fischer) Nevski](RWR), western wheatgrass [ Pascopyrum smithii (Rydb.) A. Lövc] (WW), and smooth bromegrass (Bromus inermis Leyssor) (SB), and 1 native range (NR) pasture were sampled during the study. The predominant forage species in the NR pasture were western wheatgrass, prairie junegrass [Koeleria pyramidata (Lam.) Beauv.], blue grama [Bouteloua gracilis (H.B.K.) Lag.], needleandthread (Stipa comata Trin. and Rupr.), green needlegrass (Stipa viridula Trin.), upland sedges (Carex spp.), and sweet clover [Melilotus officinalis (L.) Desr.]. Pastures were all located on upland sites. All pastures were grazed with yearling steers from 18 May through 21 September (126-day season). The RWR, WW, SB, and NR pastures were stocked at 0.93 hectares/steer, while the $C W$ pasture was stocked at 0.61 hectares/steer. The cool-season pastures were established 8 to 10 years before the study and received no fertilizer during the 3 years immediately preceding the study. Growing season (April-September) precipitation was $265 \mathrm{~mm}$, which was about $6 \%$ below normal.

Simulated diet (SD) samples were hand clipped at grazing height from each pasture by 2 individuals. Our pastures were too small to accommodate both steers maintained for production and fistula steers for periodic sampling. However, Wallace et al. (1972) reported comparable results between simulated diet samples hand clipped at grazing height and fistula diet samples collected from a 40-ha native pasture. Four of the 5 pastures sampled in this study were monocultures, thus sampling at grazing hcight should havc provided results comparable to fistula diet samples on these pastures. The fifth pasture was composed of native species, but it was only 1.86 ha in size and relatively easy to thoroughly sample by the study methods. In addition, forage mineral levels were an integral part of this work and fistula diet samples are of questionable value for mineral analyses (Langlands 1966, Hoehne et al. 1967, Scales et al. 1974).

Grazing sites were selected for clipping after observing the grazing behavior of resident steers. Grazing locations, plant parts, and, in native pastures, also plant species being grazed were mentally noted. Individuals operated independently of each other. Samples were collected in areas that had been recently grazed. Forage around dung spots was avoided. Based on experience, approximately 45 minutes and 20 locations were required per pasture to assure adequate time for observation of grazing steers and forage sampling. I ocations were randomly selected and subsampled to provide a representative composite sample containing 50 to $80 \mathrm{~g}$ dry matter.

Mower clipped (MC) strips 0.3 by 3.0 meters were taken in each pasture at 2 randomly selected sites. A random sample of about 100 g forage dry matter was collected from each swath and hand

Table 2. Correlation coefficients between simulated diet and fecal chemical composition data using residuals and unadjusted data.

\begin{tabular}{|c|c|c|c|c|c|c|c|c|}
\hline \multirow[b]{2}{*}{ Data } & \multicolumn{8}{|c|}{ Constituent } \\
\hline & $\mathbf{n}^{1}$ & IVDOM $^{1}$ & $\bar{N}$ & $\mathrm{ADF}^{1}$ & Lignin & Cellulose & $\mathrm{Ca}$ & $\mathrm{P}$ \\
\hline Residuals $^{2}$ & 40 & $0.43^{*}$ & $0.51^{*}$ & $0.45^{*}$ & 0.15 & 0.16 & $0.84^{*}$ & $0.69 *$ \\
\hline Unadjusted & 40 & $0.60^{*}$ & $0.72^{*}$ & $0.72^{*}$ & $0.58^{*}$ & $0.50^{*}$ & $0.74^{*}$ & $0.86^{*}$ \\
\hline \multicolumn{9}{|l|}{ By Date 3} \\
\hline 14 Jun & 5 & 0.25 & 0.07 & $-0.91^{*}$ & 0.67 & -0.61 & 0.42 & 0.50 \\
\hline $28 \mathrm{Jun}$ & 5 & 0.62 & 0.73 & -0.06 & 0.40 & 0.00 & 0.49 & 0.65 \\
\hline $12 \mathrm{Jul}$ & 5 & 0.79 & $0.92^{*}$ & 0.84 & 0.22 & 0.10 & $0.92^{*}$ & $0.91^{*}$ \\
\hline $26 \mathrm{Jul}$ & 5 & 0.87 & 0.21 & 0.32 & $0.91^{*}$ & 0.26 & $0.94^{*}$ & 0.69 \\
\hline 9 Aug & 5 & 0.69 & 0.63 & 0.22 & 0.13 & -0.37 & 0.59 & 0.67 \\
\hline $23 \mathrm{Aug}$ & 5 & 0.75 & $0.93^{*}$ & 0.55 & -0.06 & 0.40 & 0.87 & 0.30 \\
\hline $6 \mathrm{Sep}$ & 5 & 0.77 & 0.28 & 0.87 & 0.45 & 0.56 & $0.95^{*}$ & 0.34 \\
\hline $19 \mathrm{Sep}$ & 5 & 0.67 & 0.20 & $0.90^{*}$ & 0.75 & 0.86 & $0.97^{*}$ & 0.20 \\
\hline \multicolumn{9}{|l|}{ By Pasture 3} \\
\hline $\mathrm{RWR}^{4}$ & 8 & $-0.75^{*}$ & $0.78^{*}$ & $0.81^{*}$ & $0.84^{*}$ & 0.68 & 0.60 & $0.97 *$ \\
\hline$W^{4}$ & 8 & $0.73^{*}$ & 0.45 & 0.69 & $0.72^{*}$ & 0.06 & $0.84^{*}$ & $0.83^{*}$ \\
\hline $\mathrm{CW}^{4}$ & 8 & $0.94^{*}$ & 0.60 & 0.67 & 0.39 & 0.57 & 0.17 & $0.92^{*}$ \\
\hline $\mathrm{SB}^{4}$ & 8 & -0.43 & $0.75^{*}$ & $0.70^{*}$ & 0.39 & $0.79^{*}$ & $0.81^{*}$ & $0.94^{*}$ \\
\hline$N^{4}$ & 8 & $0.91^{*}$ & $0.86^{*}$ & $0.90^{*}$ & 0.49 & 0.51 & $0.84^{*}$ & $0.95^{*}$ \\
\hline
\end{tabular}

$\mathrm{I}_{\mathrm{n}}=$ number of pairs, IVDOM $=$ in vitro digestible organic matter, $\mathrm{ADF}=$ acid detergent fiber.

${ }^{2}$ Residuals were obtained from the SAS GLM analysis by utilizing the $P$ option.

${ }^{3}$ Data were not adjusted for pasture or date effects.

${ }^{1} \mathrm{RWR}=\mathrm{Russian}$ wildrye, $\mathrm{WW}=$ western wheatgrass, $\mathrm{CW}=$ crested wheatgrass, $\mathrm{SB}=$ Smooth brome, $\mathrm{NR}=$ native range.

*Coefficients significantly different from zero at $P<0.05$. 
separated in the laboratory, with only plant material from the current year's growth used for chemical analysis. Mower swaths contained a large amount of standing dead material and grazing animals selected little of this forage. Forage samples were collected by both methods biweekly from 14 June to 20 September 1983 .

Fecal samples were collected 2 days following forage collections from 2 steers that grazed in each pasture throughout the study. Fresh fecal samples were obtained immediately after defecation and sealed in plastic bags. After sampling, the material was immediately taken to the laboratory and dried to a constant weight in a forced air oven at $70^{\circ} \mathrm{C}$. Fecal samples were turned after crusting and broken into smaller pieces to facilitate rapid drying.

Forage samples collected during the course of the study were dried in a forced draft oven at $60^{\circ} \mathrm{C}$. Forage and fecal samples were ground through a 1-mm screen before being analyzed for in vitro digestible organic matter (IVDOM) (Tilley and Terry 1963 as modified by Moore and Mott 1974), acid detergent fiber (ADF), permanganate lignin, and cellulose (Van Soest and Wine 1968). Following wet oxidation of the organic matter, $N$ and $P$ were determined with a Technicon autoanalyzer (Technicon Industrial Systems, Tarrytown, N.Y. 10591). Atomic absorption was used to determine the concentration of calcium (Ca) in both forage and fecal samples and magnesium $(\mathrm{Mg})$ and potassium $(\mathrm{K})$ in forage samples.

Mower clipped, SD and fecal data were analyzed separately as randomized complete blocks with repeated measures (sampling dates). Variance components for error $A$ and error $B$ for $M C$ and SD data were compared via F-ratios. Error $A$ was the pasture by individual or pasture by mower strip interaction and error $B$ was a combination of the date by pasture interaction and the 3-way interaction. Mower clipped, SD, and fecal data were analyzed further using GLM procedures (SAS Institute 1985) to determine the most appropriate linear and quadratic effects over sampling dates and possible interactions among pastures. Residuals were obtained from the GLM analyses by utilizing the P option. Correlation coefficients were calculated using both residuals and unadjusted data so that the effects of date and pasture on coefficients could be examined. F-ratios, linear and quadratic effects, and correlation coefficients were considered significant at the $5 \%$ probability level.

\section{Results and Discussion}

Variance estimates for error A were significantly $(P<0.05)$ lower for SD than MC data with respect to IVDOM, $\mathrm{Ca}$, and $\mathrm{Mg}$ and significantly $(P<0.05)$ higher with respect to lignin (Table 1$)$. Variances for other chemical components were similar between sampling methods. This indicates that variability between individuals was less than or equal to variability between mower strips for all chemical components except lignin. Variances for error B were lower for SD data with respect to $\mathrm{Ca}, \mathrm{P}, \mathbf{M g}$, and $\mathrm{K}$. There were no significant differences between variances for other chemical components studied. This further suggests that there was less data variability when samples were collected by individuals than when they were obtained by random mowing with hand separation of the current year's growth. Since variances were not homogenous between forage sampling methods for several of the chemical components, data could not be further compared by analysis of variance.

Correlation coefficients between SD and MC data using residuals were low for most variables examined with only significant $(P<$ $0.05)$ coefficients for $\mathrm{N}(r=0.33)$, lignin $(r=0.37)$, and $\mathrm{P}(r=0.48)$. It is well documented that grazing cattle select a higher quality diet than is represented by available forage (Bredon et al. 1967, Wallace et al. 1972), thus low correlation coefficients between SD and MC data were not surprising. The only significant $(P<0.05)$ coefficients between MC and fecal residuals were with $N(r=0.56)$ and
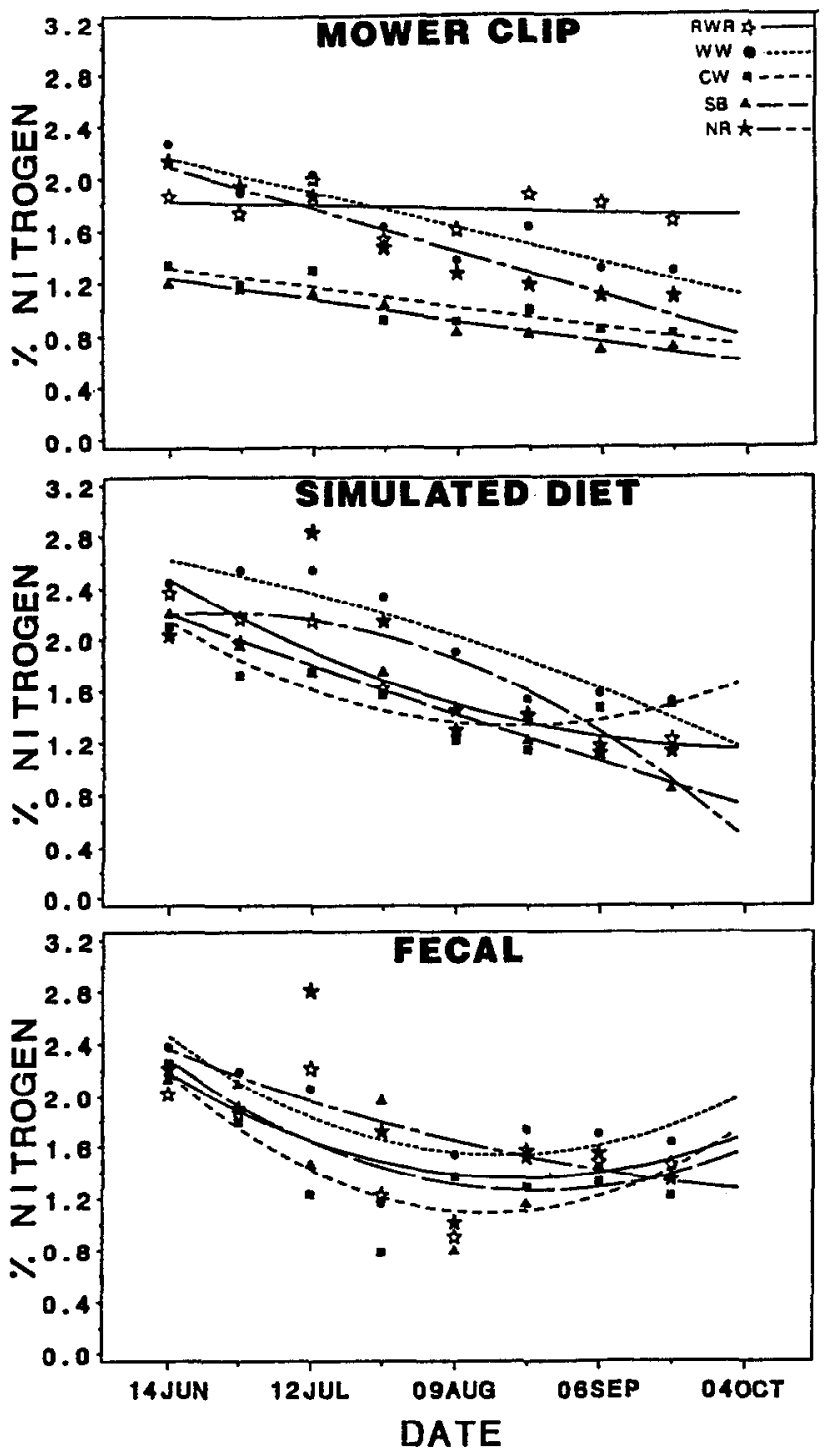

Fig. 1. Regression analysis of nitrogen concentration by pastures and sampling date for mower clip, simulated diet, and fecal data. RWR = Russian wildrye, $\mathbf{W W}=$ western wheatgrass, $C W=$ crested wheatgrass, $\mathbf{S B}=$ smooth bromegrass, and $\mathbf{N R}=$ native range.

ADF $(r=0.38)$. The highest correlation coefficients between SD and fecal residuals for a given component were for $\mathrm{N}, \mathrm{Ca}$, and $\mathrm{P}$ (Table 2).

Dietary and fecal $\mathrm{N}$ in elk (Cervus elaphus nelsoni) has been reported by Mould and Robbins (1981) to be highly related $(r=$ 0.98 ). In cattle, dietary and fecal $N$ relationships have been reported from $r=0.62$ (Squires and Siebert 1983) to $r=0.96$ (Hinnant and Kothmann 1980). It is possible that some of the variation reported in the literature results from confounding effects. In the present study large differences were found in coefficients depending on how the data were correlated. Using residual data to eliminate date and pasture effects on $\mathbf{4 0}$ observations, SD and fecal $\mathrm{N}$, although significantly correlated, resulted in a low coefficient (Table 2) compared to the literature. When unadjusted data on $\mathbf{4 0}$ observations were used, the coefficient was higher and on some individual sampling dates the coefficient exceeded $r=$ 0.90 . Unadjusted data from the NR pasture resulted in the highest coefficient, which is comparable to data $(r=0.82)$ reported by Hakkila et al. (1988). However, it is possible that both sets of data were influenced by date of sampling effects. In this study, correlat- 

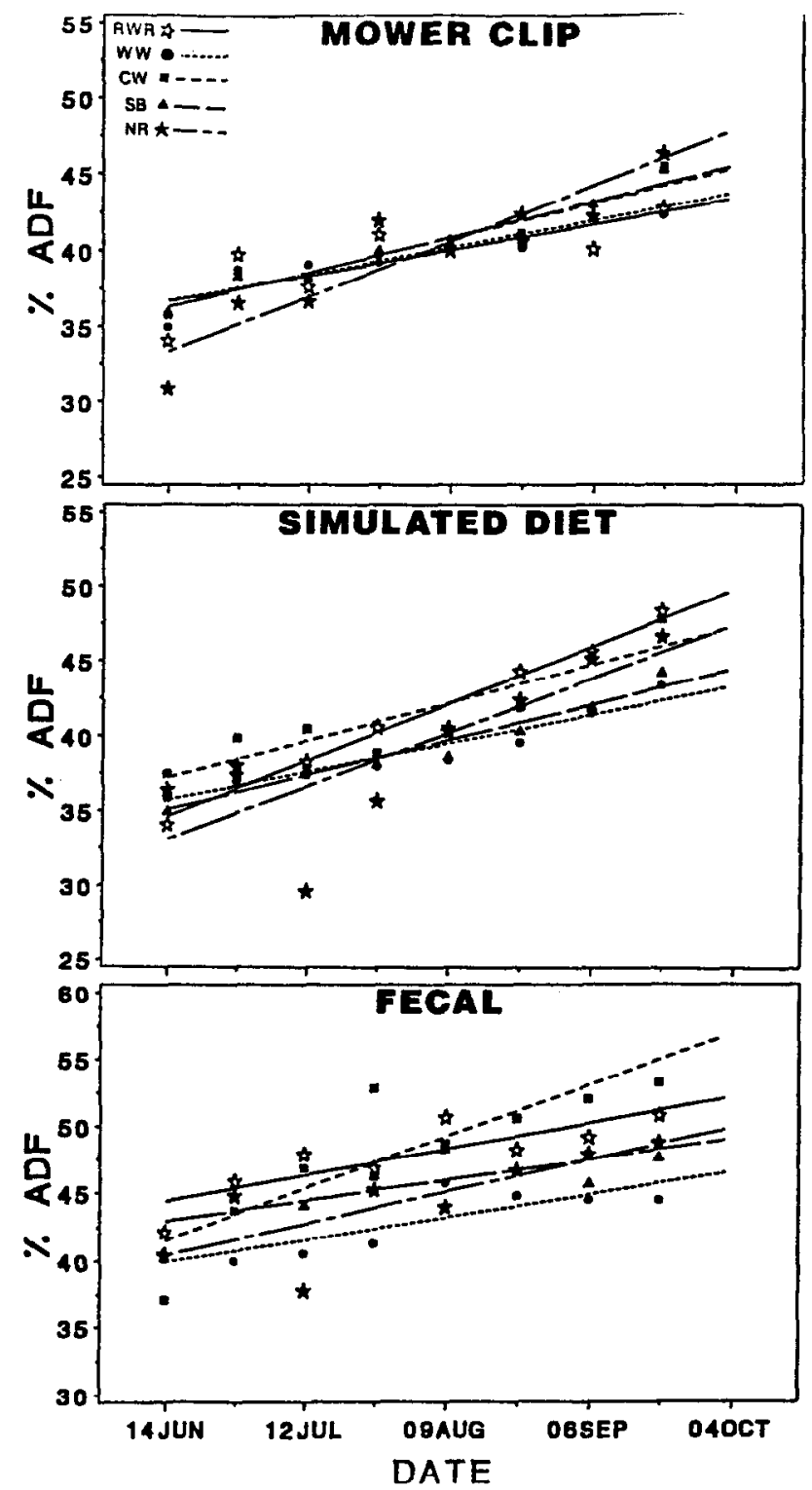

Fig. 2. Regreadion analysis of acid detergent fiber concentration by pasture and sampling date for mower clip, simulated diet and fecal data. RWR = Russian wlidrye, $\mathbf{W W}=$ western wheatgrass, $C W=$ crested wheatgrass, SB = smooth bromegrass, and $\mathbf{N R}=$ mative range.

ing data by pasture rather than by sampling date resulted in more significant $(P<0.05)$ coefficients for all constituents except $\mathrm{Ca}$ (Table 2).

Simulated diet and fecal $P$ were significantly $(P<0.05)$ correlated using residuals, but the coefficient using unadjusted data was higher and compared more closely to data reported by Holechek et al. (1985) $(r=0.95)$. Comparing sampling date coefficients calculated with unadjusted SD and fecal $P$ data show that only the 12 July date resulted in a significant $(P<0.05)$ coefficient; but when the data were correlated by pasture, SD and fecal $P$ were highly correlated for all pastures. The difference between correlation coefficients using residuals and unadjusted data illustrates the need to evaluate correlation coefficients carefully to be sure relationships are based solely on main effects.

Fecal and SD Ca were highly correlated using both residual and unadjusted data. In contrast to other single component coefficients residual data resulted in the highest coefficient (Table 2). Since the primary route of $\mathrm{Ca}$ excretion is feces (NRC 1984), forage and fecal
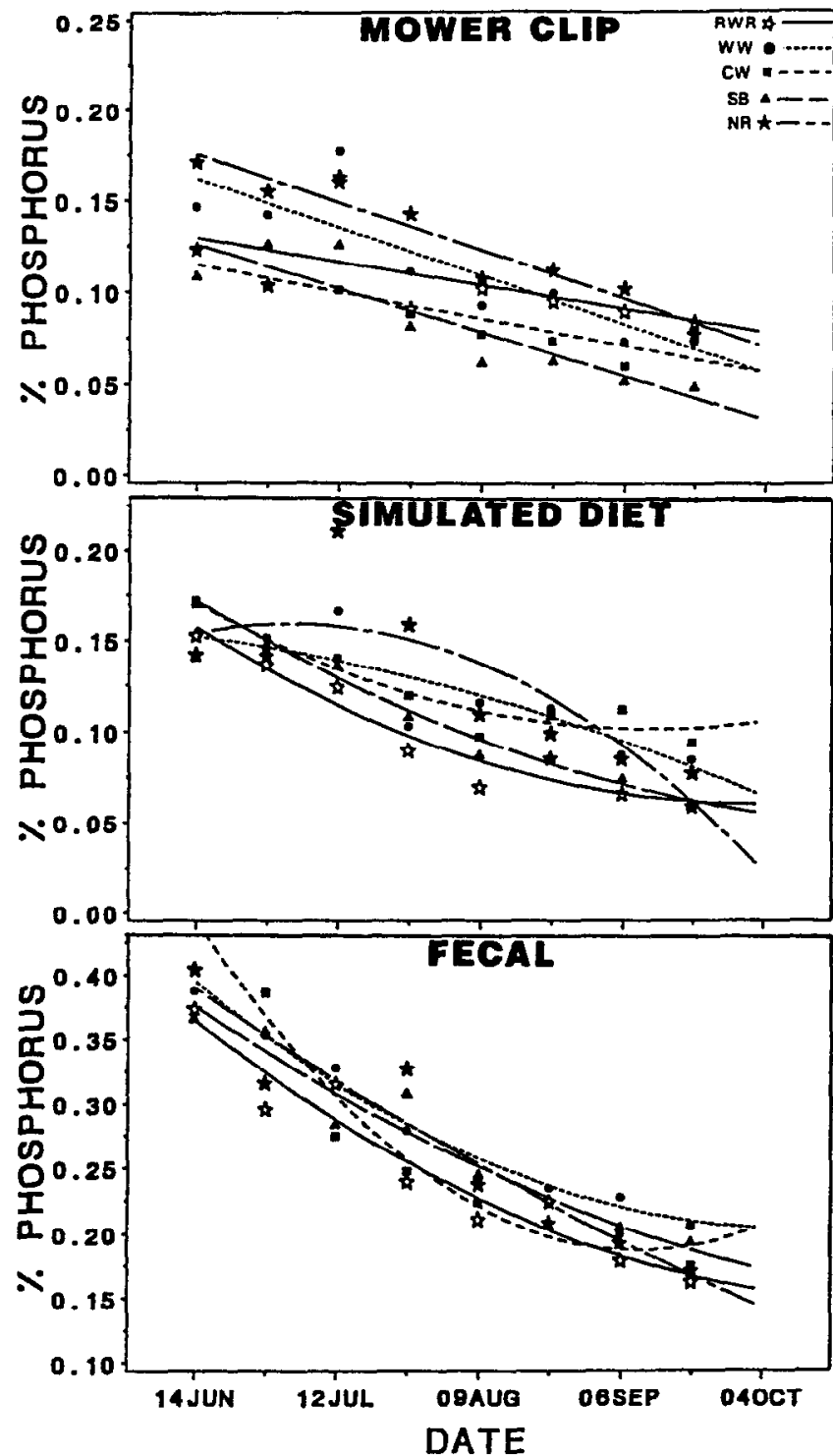

Fig. 3. Regrescion analysis of phosphorus concentration by pasture and sampling date for mower clip, simulated diet and fecal data. RWR = Russian wildrye, $W W=$ western wheatgrass, $C W=$ crested wheatgrass, $\mathrm{SB}=$ smooth bromegrass, and $\mathrm{NR}=$ native range.

$\mathrm{Ca}$ should be highly correlated when dietary $\mathrm{Ca}$ is well above the animal's requirement. The mean $\mathrm{Ca}$ level across pastures and dates in this study was $0.44 \%$ in SD samples. The Ca requirement for yearling steers is about $0.28 \%$ (NRC 1984), thus at most times during the season a substantial amount of ingested $\mathrm{Ca}$ was excreted. Using residual data, fecal $\mathrm{Ca}$ was negatively correlated with SD ADF $(r=-0.84)$ and cellulose $(r=-0.81)$, and positively correlated with $\mathrm{SD} \mathrm{N}, \mathrm{Mg}$, and $\mathrm{P}, r=0.74,0.81$, and 0.68 , respectively. Using residual data, fecal $P$ was also negatively correlated with SD ADF $(r=-0.83)$ and cellulose $(r=-0.74)$, while it was positively correlated with SD IVDOM, $\mathrm{N}, \mathrm{Ca}$, and $\mathbf{M g}, r=0.76$, $0.66,0.68$, and 0.67 , respectively.

Nitrogen concentration declined with time for MC, SD, and fecal data for all pastures (Fig. 1). However, the pattern of decline differed among pastures and forage assessment methods. Linear and quadratic responses of chemical composition data over sampling dates and possible interactions between these responses and pastures were obtained. There was a significant $(P<0.05)$ pasture by 

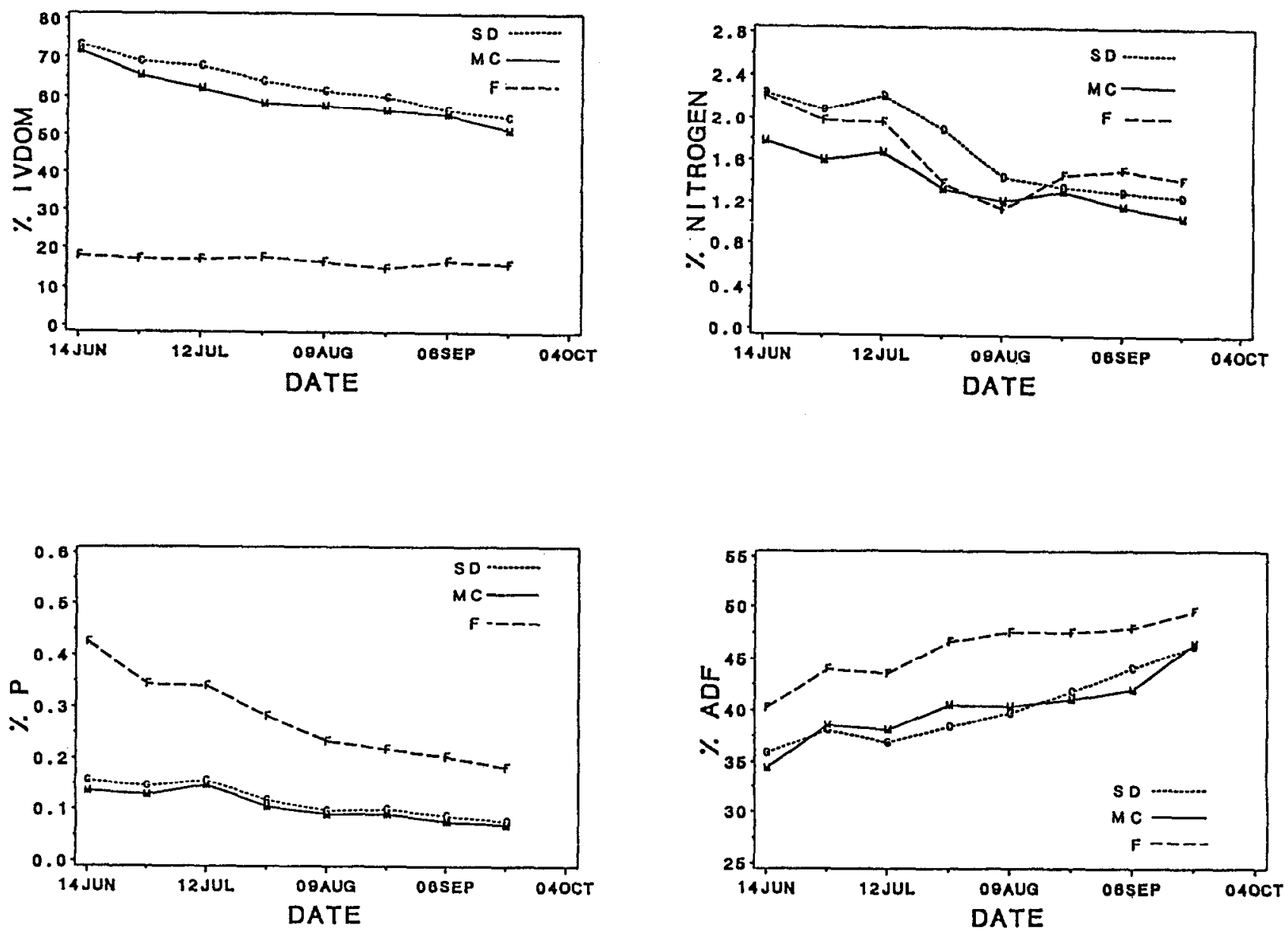

Fig. 4. In vitro digestible organic matter, nitrogen, phosphorus, and acid detergent fber concentrations by sampling date for simulated diet (SD), mower clip (MC), and fecal (F) data.

quadratic interaction for SD data and a pasture by linear interaction for MC data. Fecal $\mathrm{N}$ declined in a quadratic manner over sampling dates for all pastures. The SB pasture appeared to have the lowest $\mathbf{N}$ content in MC but not in SD samples. Fecal $\mathbf{N}$ appeared to be lowest in the $\mathrm{CW}$ pasture.

Acid detergent fiber increased linearly in forage and feces over time for all pastures (Fig. 2). However, there was a significant $(P<0.05)$ pasture by linear interaction for MC, SD, and fecal data indicating that changes in ADF among pastures over time were different. Pasture changes over time were not consistent among $\mathrm{MC}, \mathrm{SD}$, and fecal data.

Phosphorus declined over time for MC, SD, and fecal data, but the rate of decline appeared to be greatest in fecal data (Fig. 3). There was a significant $(P<0.05)$ pasture by quadratic response over sampling dates for SD and fecal $P$ concentration, while MC data showed no significant difference among pastures with respect to the linear decline in $\mathbf{P}$.

There was a significant $(P<0.05)$ pasture by quadratic interaction over sampling dates for cellulose and $\mathrm{Ca}$ in $\mathrm{MC}$ data and for $\mathrm{K}$ in SD data (data not shown). There was a significant $(P<0.05)$ quadratic effect for lignin in SD data and $\mathrm{Ca}$ in fecal data. Lignin in MC and fecal data and $\mathrm{K}$ in MC data changed linearly over time. All other variables examined with respect to $M C, S D$, or fecal data had a significant $(P<0.05)$ pasture by linear interaction effect over sampling dates. Phosphorus, ADF, cellulose, and IVDOM changes among pastures and times were significant $(P<0.05)$ for the same effects in SD and fecal data, while ADF, IVDOM, and lignin were significant $(P<0.05)$ for the same effects for $\mathrm{MC}$ and fecal data.
Phosphorus and IVDOM in SD and MC data appeared to decline together throughout the experiment (Fig. 4). Fecal IVDOM was very low and changed little with time. Fecal $P$ concentrations were much higher than forage $\mathbf{P}$, but appeared to decline in a similar manner. Simulated diet $N$ appeared to be higher than $M C$ $\mathrm{N}$ on most sampling dates. Fecal and forage $\mathbf{N}$ concentrations fall in the same general range of values. Fecal ADF appeared to change with changes in forage ADF, but fecal ADF concentrations were higher as would be expected.

Results of this work suggest that SD forage samples can be obtained over a variety of pastures by individuals with similar or less variability than would be expected by MC samples. Data also suggest (Fig. 4) that SD samples generally appeared to be higher in quality than MC hand-separated samples. Correlation coefficients suggested a closer relationship between SD and fecal data than between $\mathrm{MC}$ and fecal data. The data also demonstrate the need for care when using correlation analysis to substantiate biological relationships. Interactions between pastures and linear or quadratic effects over time also demonstrate more common effects between SD and fecal samples than between SD and MC or MC and fecal data. Fecal $\mathrm{Ca}$ may be useful in predicting forage $\mathrm{Ca}$ as well as ADF, cellulose, and Mg. However, further examination of forage and fecal relationships are necessary to determine whether there are consistent reliable relationships which can be exploited to indirectly monitor pasture quality. 


\section{Literature Cited}

Bredon, R.M., D.T. Torell, and B. Marshall. 1967. Measurement of selective grazing of tropical pastures using esophageal fistulated steers. J. Range Manage. 20:317-320.

Erasmus, T., B.L. Penzhorn, and N. Fairall. 1978. Chemical composition of faeces as an index of veld quality. S. Afr. J. Wildl. Res. 8:19-24.

Hakkila, M., J.L. Holechek, J.D. Wallace, D.M. Anderson, and M. Carenas. 1988. Fecal indicators of cattle protein status on desert grassland range. Nutr. Rep. Int. 37:137-147.

Hart, R.H., O.M. Abdalla, D.H. Clark, M.B. Marshall, M.H. Hamid, J.A. Hager, and J.W. Waggoner, Jr. 1983. Quality of forage and cattle diets on the Wyoming High Plains. J. Range Manage. 36:46-51.

Hinnant, R.T., and M.M. Kothmann. 1980. Predicting dietary crude protein from blood, rumen fluid, and fecal components. p. 18. In. Abstr. 33rd Annu. Meeting Soc. Range Manage., San Diego, Calif.

Hoehne, O.E., D.C. Clanton, and C.L. Streeter. 1967. Chemical changes in esophageal fistula samples caused by salivary contamination and sample preparation. J. Anim. Sci. 26:626-631.

Holechek, J.L., M.L. Galyean, J.D. Wallace, and H. Wofford. 1985. Evaluation of faecal indices for predicting phosphorus status of cattle. Grass and Forage Sci. 40:489-492.

Langlands, J.P. 1966. Studies on the nutritive value of the diet selected by grazing sheep. I. Differences in composition between herbage consumed and material collected from oesophageal fistulae. Anim. Prod. 8:253-259.
Moore, J.E., and G.O. Mott. 1974. Recovery of residual organic matter from in vitro digestion of forages. J. Dairy Sci. 57:1258-1259.

Mould, E.D., and C.T. Robbins. 1981 Nitrogen metabolism in elk. J. Wildl. Manage. 45:323-334.

National Research Council. 1984. Nutrient requirements of domestic animals. Nutrient requirements of beef cattle. 6th Ed. Nat. Acad. Sci. Washington, D.C.

SAS Institute, Inc. 1985. SAS User's Guide: Statistics. SAS Institute, Inc., Cary, N.C.

Scales, G.H., C.L. Streeter, A.L. Denham, and G.W. Ward. 1974. Effect of mastication, salivary contamination and leaching on the chemical composition of forage samples collected via esophageal fistulae. J. Anim. Sci. 38:1278-1283.

Squires, V.R., and B.D. Siebert. 1983. Botanical and chemical components of the diet and liveweight change in cattle on semi-desert rangeland in central Australia. Aust. Range. J. 5:28-34.

Tilley, J.M.A., and R.A. Terry. 1963. A two-stage technique for the in vitro digestion of forage crops. J. Br. Grassl. Soc. 18:104-111.

Van Soest, P.J., and R.H. Wine. 1968. Determination of lignin and cellulose in acid-detergent fiber with permanganate. J. Assoc. Official Anal. Chem. 51:780-785.

Wallace, J.D., J.C. Free, and A.H. Denham. 1972. Seasonal changes in herbage and cattle diets on sandhill grassland. J. Range Manage. 25:100-104. 